DOI: https://doi.org/10.18371/fp.3(35).2019.190174

УДК 338.246 .28

\title{
ВИЗНАЧЕННЯ ЕФЕКТИВНОСТІ ВИКОРИСТАННЯ ІННОВАЦІЙНОГО ПОТЕНЦІАЛУ УКРАЇНИ ЗА ДОПОМОГОЮ МЕТОДА БАГАТОВИМІРНОЇ СЕРЕДНЬОї
}

\author{
ЧЕРКАШИНА Тетяна Сергіївна \\ к.е.н., дочент кафедри економічної теорії та економічної політики \\ Харківського національного економічного університету \\ імені С. Кузнеия \\ e-mail:t.cherkashina@hotmail.com
}

Аннотація. Проведено оичнку ефективності використання інноваційного потенціалу національної економіки України у 2014-2018 рр. У якості інструмента оцінювання був використаний метод багатовимірної середньої, який дав автору змогу встановити, що серед дев'яти країн, які мають на меті приєднатися до СС і НАТО, Украӥна за рівнем інноваційного потенціалу посідає перше місце. У той же час складним $i$ суперечливим залишається питання ефективності використання національного інноваційного потенцііалу, щуо проявляється у невисокій ринковій вартості інтелекттуальних активів країни $i$ обумовлено недостатньою державною підтримкою галузей з високою доданою вартістю. 3 огляду на ие автором запропоновано наступне: державне фінансування нових, більш прогресивних технологій; створення більш сприятливих інституційних умов для ведення наукоємного бізнесу; суттєве удосконалення організачійно-економічного механізму комериіалізації науково-дослідних робіт $i$ захисту прав інтелектуальної власності.

Ключові слова: інноваційний потенціал, освітній потенціал, науковий потенціал, інформаційний потенціал, людський потенціал, національна інноваційна система, метод багатовимірної середньої, європейська інтеграчія, Свропейський Союз (СС), євроатлантичне співробітництво, Північноатлантичний альянс (НАТО).
Аннотация. Проведена оценка эффективности использования инноваџионного потенциала национальной экономики Украины в 2014-2018 г2. В качестве инструмента оченивания был использован метод многомерной средней, который позволил автору установить, что среди девяти стран, которые ставят задачу стать членами ЕС и НАТО, Украина по уровню инновачионного потенциала занимает первое место. В то же время сложным и противоречивым остается вопрос эффективности его использования, что проявляется в невысокой рыночной стоимости интеллектуальных активов страны. В связи с этим автором предложено, что государственное финансирование новых, более прогрессивных технологий; создание более благоприятных институциональных условий для ведения наукоемного бизнеса; существенное совершенствование организационно-экономического механизма коммерциализачии научно-исследовательских работ и защиты прав интеллектуальной собственности.

Ключевые слова: инновационный потенцииал, образовательный потенцииал, научный потенциал, информационный потенцииал, человеческий потенцииал, национальная инновационная система, метод многомерной средней, европейская интеграчия, Европейский Союз (ЕС), евроатлантическое сотрудничество, альянс Североатлантический (HATO 
Постановка проблеми. Одним 3 ключових завдань економічного розвитку України до 2030 p. $є$ динамізація процесів європейської інтеграції та євроантлантичного співробітництва i подальший вступ країни до Європейського Союзу (СС) i Північноатлантичного альянсу (НАTO). Це вимагає докорінної зміни пріоритетів державної економічної політики України та прискорення структурно-ринкових реформ на засадах інноваційної модернізації іiі наукового, інтелектуального, технологгічного та людського потенціалу. 3 огляду на це вивчення питань, пов'язаних 3 визначенням ефективності використання інноваційного потенціалу національної економіки України та розробкою організаційноекономічних механізмів підвищення ефективності його використання, $\epsilon$ актуальним науково-практичним завданням.

Аналіз останніх досліджень i публікацій. Докладний аналіз публікацій, присвячених даній проблематиці, показав, що в сучасній економічній науці існує три групи методологічних підходів до оцінювання національного інноваційного потенціалу. Перша група науковців досліджує ефективність використання національного інноваційного потенціалу за допомогою визначення часткових i загальних показників, експертної оцінки коефіцієнтів їх значущості і розрахунку на цій основі інтегрального показника інноваційного потенціалу національної економіки. До цієї групи належать такі економісти як С. Алєксєєв, М. Буянова, А. Гусейнлі [2],
А. Гусейнова [2], Е. Менсфілд, Р. Нельсон, Х. Ріггс, А. Трухляєва, О. Шукурова [2] та ін.

Представники іншої групи використовують переважно матричні методи, що дозволяють оцінити кількісні пропорції між різними складовими інноваційного потенціалу. Іншими словами, для визначення ефективності використання національного інноваційного потенціалу економісти аналізують міжгалузеві спів відношення інноваційних потенціалів різних регіонів i галузей i на цій основі будують спеціальну матрицю. Даного наукового підходу дотримуються такі вчені як $Є$. Губанова, В. Едвард [16], Дж. Шот [16].

Третя група методологічних підходів до визначення ефективності використання національного інноваційного потенціалу базується на використанні бальних методів. У цьому випадку вчені (Б. Бозкурт [16], I. Дубіна, Дж. Едлер [12], Т. Остащенко, А. Рембе, Е. Пашера, Дж. Факерберг [12-13] та ін.) для оцінки часткових показників використовують спеціальні шкали, зокрема шкалу Лайкерта і шкалу Раша. У межах даної групи підходів існує також методика, заснована на формуванні порівняльних рейтингових таблиць, запропонована С. Масалітиним і Т. Арцером.

$\mathrm{У}$ той же час питання ефективності інноваційного потенціалу національної економіки України вже ще залишається невирішеним і потребує подальшого, більш поглибленого наукового аналізу.

Метою даного дослідження $\epsilon$ визначення ефективності вико ристання інноваційного потенціалу націо- 
нальної економіки України за допомогою метода багатовимірної середньої та розробка на цій основі напрямів підвищення ефективності його використання на етапі європейської інтеграції та євроатлантичного співробітництва.
Виклад основного матеріалу. Визначення ефективності використання інноваційного потенціалу національної економіки України на етапі європейської інтеграції та євроантлантичного співробітництва (2014-2018 рр.) була проведена у три етапи (рис. 1).

Етап 1. Формування переліку показників, які характеризують складові інноваційного потенціалу національної економіки

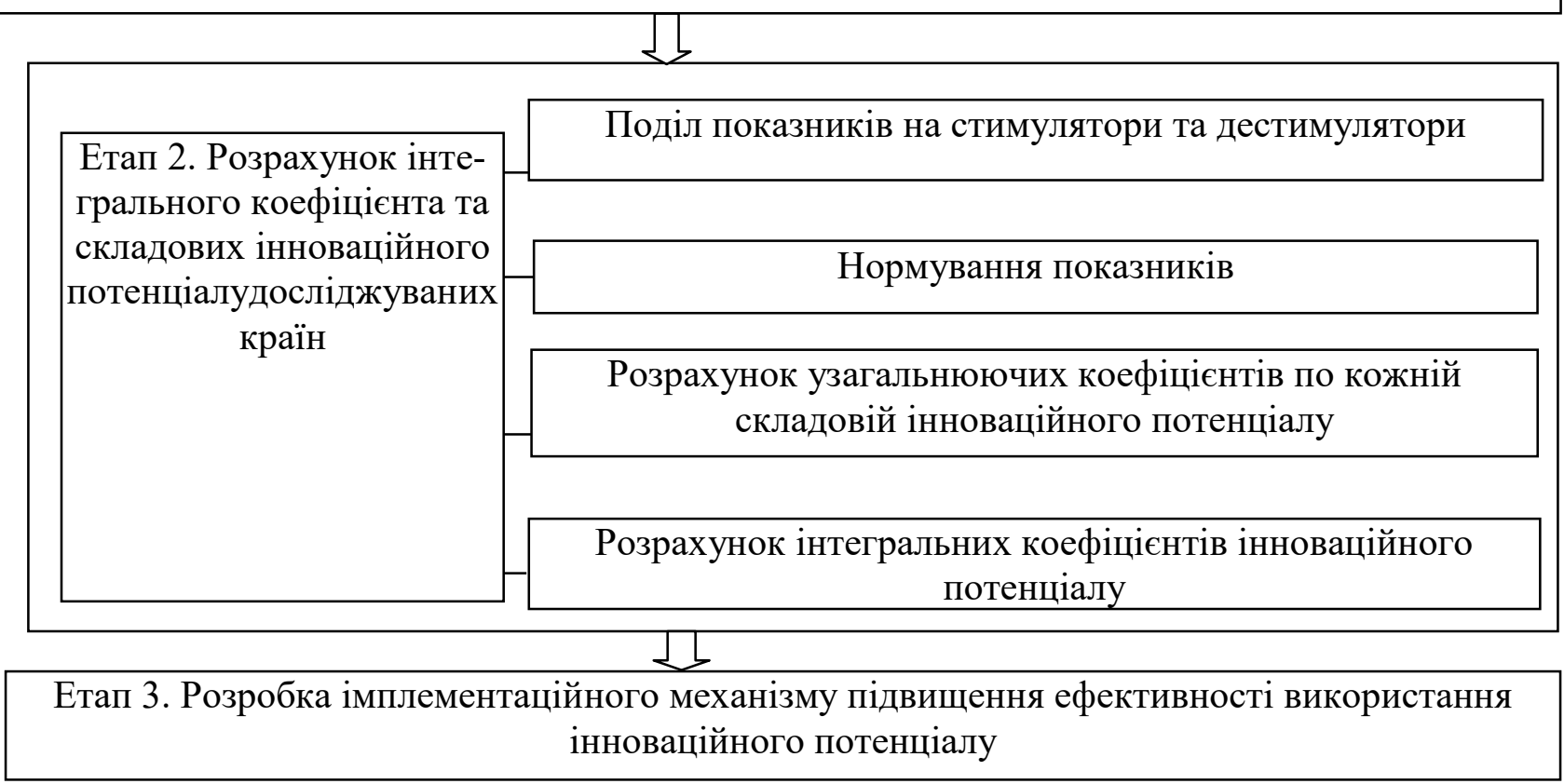

Рис. 1. Послідовність етапів визначення ефективності використання інноваційного потенціалу національної економіки України за допомогою багатовимірної середньої

На першому етапі було сформовано перелік часткових показників, які характеризують складові інноваційного потенціалу національної економіки на етапі європейської інтеграції та євроантлантичного співробітництва. Як відомо, інноваційний потенціал національної економіки - це сукупність умов, ресурсів і факторів, які характеризують здатність i готовність країни до інноваційної діяльності та спрямовані на виробництво високотехнологічної про- дукції, що є конкурентоспроможною на світових товарних ринках $[1$, с. $54-$ $58 ; 2 ; 12$, с. 4-6]. Детальне вивчення існуючих джерел $[2 ; 10$, с. 59-67; 16; 18 , с. 110] та результати власних наукових пошуків [14] дозволили виділити у структурі інноваційного потенціалу національної економіки чотири основні складові: освітній потенціал, науковий потенціал, інформаційний потенціал, людський потенціал.

Освітній потенціал національної 
економіки - це сукупність умов, ресурсів i факторів, які характерризують динаміку інституційних i соціальних інвестицій в освіту, професійне навчання та підвищення кваліфікації населення і забезпечують підготовку висококваліфікованих фахівців, здатних генерувати, виробляти та споживати продукти інтелектуальної власності. Освітній потенціал національної економіки характерризується такими показниками [2; 12, c. 16-19]:

1) показник витрат на освіту, який розраховується у такий спосіб:

$$
\text { По }=\frac{\text { ДВо }}{\text { ВВПн }},
$$

де По - показник витрат на освіту; ДВ $\mathrm{O}_{\mathrm{O}}$ - обсяг державних витрат на освіту;

\section{ВВП;}

$\mathrm{BBП}_{\mathrm{H}}$ - обсяг номінального

2) показник забезпеченості сфери освіти педагогічними кадрами, який розраховується у такий спосіб:

$$
\text { Ппк }=\frac{B}{y},
$$

де $\Pi_{\Pi к}-$ показник забезпеченості сфери освіти педагогічними кадрами;

В - кількість вчителів;

У - кількість учнів.

Науковий потенціал національної економіки - це сукупність умов, ресурсів і факторів, які формуються та реалізуються через мережу закладів вищої освіти (ЗВО), а також технопаркові та смарт-структури, i створюють інформаційно-інтелектуальне підгрунтя для появи нових наукових ідей i проектів. Науковий потенціал національної економіки характеризується такими показниками [13, c. 499-501; 18, c. 107-109]:
1) показник витрат на наукову та інноваційну діяльність, який розраховується у такий спосіб:

$$
\text { Пні }=\frac{\text { ДВні }}{\text { ВВПн }},
$$

де $\Pi_{\mathrm{HI}}-$ показник витрат на наукову та інноваційну діяльність;

ДВ на наукову та інноваційну діяльність;

2) показник видавничої активності населення, який розраховується у такий спосіб:

$$
\text { Пва }=\frac{\kappa_{н п}}{\kappa_{н}},
$$

де $П_{\mathrm{BA}}-$ показник видавничої активності населення;

$\mathrm{K}_{\mathrm{H \Pi}}-$ кількість примірників друкованої літератури (газет, журналів, навчальної та наукової літератури);

$\mathrm{K}_{\mathrm{H}}$ - кількість населення;

3) показник цитованості наукових статей, який розраховується у такий спосіб:

$$
\Pi ц=\frac{К_{ц}}{\text { Кнс }},
$$

де $П_{ц}-$ показник цитованості наукових статей;

$\mathrm{K}_{ц}-$ кількість цитувань на наукові статті;

$\mathrm{K}_{\mathrm{HC}}-$ кількість наукових статей.

Інформаційний потенціал національної економіки - це сукупність умов, ресурсів і факторів, які спрямовані на створення та комерціалізацію нових знань у наукомістких галузях національного господарства - мікроелектроніці, наноелектроніці, роботобудуванні, оптико-волоконних технологіях i генній інженерії. Як правило, він представлений у вигляді новітніх комп'ютерних технологій, оригі- 
нального програмного забезпечення, науково-технічних патентів, авторських свідоцтв, промислових знаків, а також так званих «ноу-хау». Інформаційний потенціал національної економіки характеризується такими показниками [4, с. 151-154; 10, c. 92]:

1) показник користування населення мобільним зв'язком, який розраховується у такий спосіб:

$$
\text { Пмз }=\frac{\text { Кмл }}{\text { Кн }},
$$

де $П_{\mathrm{M} 3}-$ показник користування населення мобільним зв'язком;

$\mathrm{K}_{\mathrm{Mл}}$ - кількість телефонних ліній мобільного зв'язку;

2) показник користування населення Інтернетом, який розраховується у такий спосіб:

$$
\Pi \mathrm{I}=\frac{\mathrm{Ki}}{\mathrm{KH}},
$$

де $\Pi_{I}-$ показник користування населення Інтернетом;

$\mathrm{K}_{\mathrm{I}}$ - кількість користувачів Інтернетом;

3) показник витрат на інформаційно-комунікаційні технології, який розраховується у такий спосіб:

$$
\text { Пікт }=\frac{\text { ДВікт }}{\text { ВВПн }},
$$

де $\Pi_{\text {Iкт }}$ - показник витрат на інформаційно-комунікаційні технології;

ДВ на інформаційно-комунікаційні технології.

Людський потенціал національної економіки - це сукупність умов, ресурсів і факторів, які спрямовані на накопичення знань, вмінь, навичок, компетенцій i мотивацій населення країни і можуть бути потенційно використані ними на будь-якій фазі сус- пільного відтворення 3 метою створення оригінальних творів мистецтва i культури, функціональних розробок, наукових винаходів, технологічних та/або фінансових інновацій. Дана складова інноваційного потенціалу $\epsilon$ важливою для будь-якої країни, оскільки саме вона формує у кожного громадянина економічну та соціальну мотивацію бути здоровим, високоморальним, креативним і освіченим, що, у свою чергу, є основою для побудови успішного i заможного суспільства. Людський потенціал національної економіки характеризується такими показниками [9, с. 86-89; 12]:

1) показник якісної робочої сили, який розраховується у такий спосіб:

$$
\text { Пярс }=\frac{\kappa_{в о}}{К_{н}},
$$

де ПЯРС - показник якісної робочої сили;

$$
\mathrm{K}_{\mathrm{BO}} \text { - кількість осіб з вищою }
$$
освітою;

2) показник очікуваної тривалості навчання $\left(\mathrm{I}_{\mathrm{OTH}}\right)$, який розраховується експертами ООН і публікується на відповідному сайті [21].

Перевагами наведеного переліку показників (П $, \Pi_{\Pi \kappa}, \Pi_{\mathrm{HI}}, \Pi_{\mathrm{BA}}, \Pi_{ц}, \Pi_{\mathrm{M} 3}$, $\left.\Pi_{\mathrm{I}}, \Pi_{\mathrm{IKT}}, \Pi_{\text {ЯРС }}, \Pi_{\mathrm{OTH}}\right) \epsilon$ те, що він забезпечує формалізацію, взаємопов'язаність, односпрямованість та порівнянність показників, їх груп і системи в цілому; враховує вплив динамічного глобального зовнішнього середовища; дає можливість регулювати рівень інноваційного потенціалу національної економіки залежно від витрачених бюджетних коштів і очікуваного результату; дозволяє отримувати прогнозні значення щодо рівня інновацій- 
ного потенціалу національної економіки та його складових.

На другому етапі дослідження був зібраний необхідний статистичний матеріал по дев'яти країнах, які, як і Україна, мають на меті приєднатися до ЄC і НATO, тому на даний час знахо- дяться на етапі складних структурноринкових трансформацій. Такими країнами є Албанія, Боснія та Герцеговина, Грузія, Македонія, Молдова, Сербія, Туреччина, Україна і Чорногорія (таблиця 1).

Таблиця 1

Вихідні дані для оцінки інноваційного потенціалу досліджуваних країн у 2018 p.

\begin{tabular}{|c|c|c|c|c|c|c|c|c|c|}
\hline Показники & 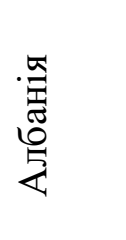 & 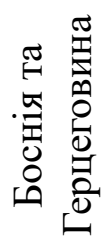 & 离 & 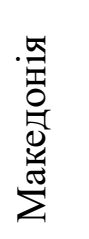 & 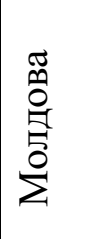 & 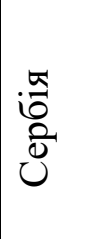 & 茎 & : & 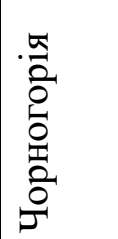 \\
\hline $\begin{array}{l}\text { Показник витрат на освіту, } \\
\%\end{array}$ & 3,5 & 3,4 & 3,8 & 3,7 & 6,7 & 4,0 & 4,4 & 5,9 & 5,8 \\
\hline $\begin{array}{lr}\text { Показник } \\
\text { сфери забезпеченості } \\
\text { педагогічними кадрами }\end{array}$ & 13,5 & 10,1 & 10,8 & 11,6 & 9,3 & 8,5 & 20,1 & 7,0 & 11,9 \\
\hline $\begin{array}{l}\text { Показник } \\
\text { витрат }\end{array}$ & 0,2 & 0,21 & 0,3 & 0,4 & 0,4 & 1,0 & 0,9 & 0,6 & 0,4 \\
\hline $\begin{array}{l}\text { Показник } \\
\text { активності населення }\end{array}$ & 5,2 & 10,2 & 16,0 & 14,2 & 13,2 & 49,2 & 17,5 & 12,2 & 21,5 \\
\hline $\begin{array}{l}\text { Показник цитованості } \\
\text { наукових статей }\end{array}$ & 1,8 & 3,0 & 7,9 & 4,9 & 4,8 & 8,3 & 25,0 & 14,9 & 0,3 \\
\hline $\begin{array}{lr}\text { Показник } & \text { користування } \\
\text { населення } & \text { мобільним } \\
\text { зв'язком, \% } & \end{array}$ & 115,2 & 96,8 & 140,9 & 98,5 & 93,3 & 130,2 & 94,4 & 135,2 & 165,6 \\
\hline $\begin{array}{l}\text { Показник } \quad \text { користування } \\
\text { населення Інтернетом, \% }\end{array}$ & 66,4 & 54,7 & 58,0 & 72,2 & 71,0 & 67,1 & 58,3 & 52,5 & 72,0 \\
\hline $\begin{array}{l}\text { Показник витрат } \\
\text { iнформаційно- } \\
\text { комунікаційні } \\
\%\end{array}$ & 1,5 & 1,4 & 1,8 & 1,5 & 1,6 & 2,1 & 2,9 & 2,8 & 1,9 \\
\hline $\begin{array}{l}\text { Показник якісної робочої } \\
\text { сили, \% }\end{array}$ & 55,9 & 84,1 & 94,4 & 80,5 & 60,7 & 60,3 & 44,0 & 98,1 & 90,1 \\
\hline $\begin{array}{l}\text { Показник очікуваної } \\
\text { тривалості навчання, років }\end{array}$ & 10,0 & 9,7 & 12,0 & 9,6 & 11,6 & 11,1 & 8 & 11,3 & 11,3 \\
\hline
\end{tabular}

Джерело: [19-20] 
3 метою забезпечення співвідносності вхідних показників їх було розподілено на стимулятори i дестимулятори та про-нормовано. У даному дослідженні стимулятори - це показники, зростання значень яких свідчить про позитивні тенденції у формуванні інноваційного потенціалу національної економіки, тому найвищому значенню показниківстимуля-торів відповідає найкращий стан націо-нальної інноваційної системи. Відповідно до стимуляторів нами віднесені показник витрат на освіту $\left(\Pi_{\mathrm{O}}\right)$, показник витрат на наукову та інноваційну діяльність $\left(\Pi_{\mathrm{HI}}\right)$, показник видавничої активності $\left(\Pi_{\mathrm{BA}}\right)$, показник цитованості наукових статей (ПЦ), показник користування мобільним зв'язком (П Мз $)$, показник користування Інтернетом $\left(\Pi_{\mathrm{I}}\right)$, показник витрат на інформаційнокомуні-каційні технології (П Ікт), показник якісної робочої сили (П показник очікуваної тривалості навчання (Потн). Нормування показників-стимуляторів було проведено за формулою:

$$
X=\frac{\text { Хффак }- \text { Хммі }}{\text { Хммак }- \text { Хммі }} \text {, }
$$

де $\mathrm{X}_{\text {факт }}$ - фактичне значення показника;

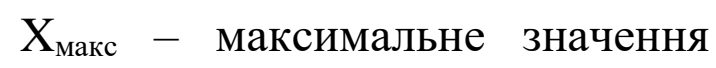
показника;

$$
\mathrm{X}_{\text {мін }} \text { - мінімальне значення пока- }
$$
зника.

Натомість дестимулятори - це показники, зростання значень яких свідчить про негативні тенденції у формуванні інноваційного потенціалу національної економіки, тому найвищому значенню показників-дестимуляторів відповідає найгірший стан національної інноваційної системи. Відповідно до стимуляторів нами віднесений лише один показник - показник забезпеченості сфери освіти педагогічними кадрами ( $\left.\mathrm{I}_{\Pi \kappa}\right)$. Нормування показника забезпеченості сфери освіти педагогічними кадрами було проведено за формулою:

$$
X=1-\frac{\text { Хффак- Хммі }}{\text { Хммак-Хммі }}
$$

Пронормовані вхідні показники, які характеризують складові інноваційного потенціалу національних економік досліджуваних країн у 2018 р., наве-

\begin{tabular}{|c|c|c|c|c|c|c|c|c|c|}
\hline Показники & 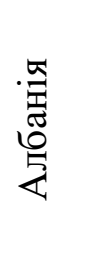 & 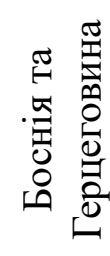 & 离 & 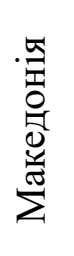 & $\begin{array}{l}\text { 兽 } \\
\text { 最 } \\
\sum^{0}\end{array}$ & în & 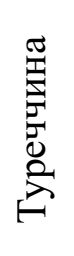 & 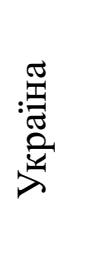 & 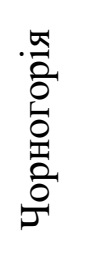 \\
\hline Показник витрат на освіту & 0,03 & 0 & 0,12 & $\begin{array}{c}0,0 \\
9\end{array}$ & 1 & 0,18 & 0,3 & 0,76 & 0,73 \\
\hline $\begin{array}{ll}\text { Показник } & \text { забезпеченості } \\
\text { сфери освіти педагогічними } \\
\text { кадрами }\end{array}$ & 0,5 & 0,76 & 0,71 & $\begin{array}{c}0,6 \\
5\end{array}$ & 0,82 & 0,89 & 0 & 1 & 0,63 \\
\hline $\begin{array}{l}\text { Показник витрат на наукову } \\
\text { та інноваційну діяльність }\end{array}$ & 0 & $\begin{array}{c}0,01 \\
25 \\
\end{array}$ & $\begin{array}{c}0,12 \\
5 \\
\end{array}$ & $\begin{array}{c}0,2 \\
5 \\
\end{array}$ & 0,25 & 0,875 & 1 & 0,375 & 0,25 \\
\hline
\end{tabular}
дені у таблиці 2.

Таблиця 2

Нормовані дані для оцінки інноваційного потенціалу досліджуваних країн 
Закінчення таблиці 2

\begin{tabular}{|c|c|c|c|c|c|c|c|c|c|}
\hline Показники & 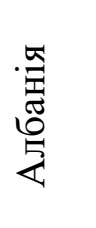 & 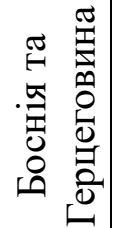 & 离 & 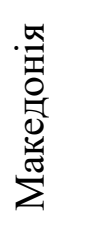 & 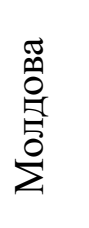 & $\begin{array}{l}\frac{\pi}{0} \\
\frac{0}{2} \\
0\end{array}$ & 苞 & : & 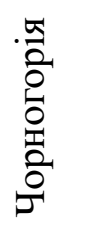 \\
\hline $\begin{array}{l}\text { Показник видавничої } \\
\text { активності населення }\end{array}$ & 0 & 0,11 & 0,25 & 0,2 & 0,18 & 1 & 0,28 & 0,16 & 0,37 \\
\hline $\begin{array}{ll}\text { Показник } & \text { цитованості } \\
\text { наукових статей } & \end{array}$ & 0,06 & 0,11 & 0,32 & 0,19 & 0,18 & 0,32 & 1 & 0,59 & 0 \\
\hline $\begin{array}{lr}\text { Показник } & \text { користування } \\
\text { населення } & \text { мобільним } \\
\text { зв'язком } & \end{array}$ & 0,3 & 0,05 & 0,66 & 0,07 & 0 & 0,02 & 0,51 & 0,58 & 1 \\
\hline $\begin{array}{l}\text { Показник користування } \\
\text { населення Інтернетом }\end{array}$ & 0,71 & 0,11 & 0,28 & 1 & 0,94 & 0,74 & 0,29 & 0 & 0,88 \\
\hline $\begin{array}{l}\text { Показник витрат } \\
\text { iнформаційно-комунікаційні } \\
\text { технології }\end{array}$ & 0,07 & 0 & 0,27 & 0,07 & 0,13 & 0,47 & 1 & 0,93 & 0,33 \\
\hline $\begin{array}{l}\text { Показник якісної робочої } \\
\text { сили }\end{array}$ & 0,24 & 0,77 & 1 & 0,72 & 0,33 & 0,32 & 0 & 1,07 & 0,91 \\
\hline $\begin{array}{l}\text { Показник очікуваної } \\
\text { тривалості навчання }\end{array}$ & 0 & 0,43 & 1 & 0,4 & 0,9 & 0,78 & 0,1 & 0,83 & 0,83 \\
\hline
\end{tabular}

Після цього були розраховані узагальнюючі коефіцієнти по кожній складовій інноваційного потенціалу досліджуваних країн за формулою:

$$
\text { УКоп }=\frac{\text { По }+ \text { Ппк }}{2} \text {, }
$$

де УКоп - узагальнюючий коефіцієнт освітнього потенціалу національної економіки;

$$
\text { УКнп }=\frac{\text { Пні }+ \text { Пва }+ \text { Пц }}{3},
$$

де УК єнт наукового потенціалу національної економіки;

$$
\text { УПіп }=\frac{\text { Пмз }+ \text { Пі }+ \text { Пікт }}{3},
$$

де УК єнт інформаційного потенціалу національної економіки;

$$
\text { УКлп }=\frac{\text { Пярс }+ \text { Потн }}{2},
$$

де УК єнт людського потенціалу національної економіки.

Також були розраховані інтегральні коефіцієнти інноваційного потенціалу національних економік досліджуваних країн як середнє геометричне узагальнюючих коефіцієнтів кожної його складової:

$$
\text { ІКіп }=\sqrt{\text { УКоп } \cdot \text { УКнп } \cdot \text { УКіп } \cdot \text { УКлп }}
$$

де ІК $_{\text {Iп }}$ - інтегральний коефіцієнт інноваційного потенціалу національної економіки.

Результати проведених розрахунків за формулами (12-16) наведені у таблиці 3.

3 табл. 3 видно, що у 2018 р. серед досліджуваних країн Україна за рівнем інноваційного потенціалу національної економіки посідала перше місце $\left(\mathrm{IK}_{\text {Iп }}=0,69\right)$. Це пояснюється високим рівнем наукового, освітнього та 
людського потенціалу, які є найвищими серед дев'яти досліджуваних країн $\left(\mathrm{IK}_{\mathrm{H \Pi}}=1,13, \mathrm{IK}_{\text {ОП }}=0,88, \mathrm{IK}_{Л п}=0,95\right)$. Тому, незважаючи на існуючі недоліки в механізмі формування та реалізації економічної політики у сфері європейської інтеграції та євроатлантичного співробітництва, Україні вдається формувати та накопичувати креативний людський потенціал і приймати активну участь у дослідницьких та освітніх програмах ЄС. Відтак, можна впевнено стверджувати про те, що серед країн, які претендують на членство у ЄС і НАТО, саме Україна має найбільші потенційні можливості для успішної конвергенції з єдиною господарською системою ЄС і залучення глобальних інвестиційних ресурсів.

Таблиця 3

Розрахунок інтегральних коефіцієнтів інноваційного потенціалу досліджуваних країн у 2018 p.

\begin{tabular}{|c|c|c|c|c|c|c|c|c|c|}
\hline Показники & 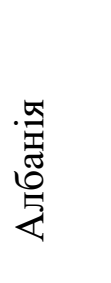 & 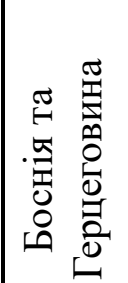 & 离 & 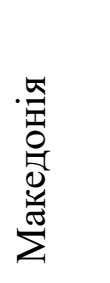 & $\begin{array}{l}\widetilde{0} \\
\stackrel{0}{0} \\
\text { 景 } \\
\stackrel{0}{\Sigma}\end{array}$ & 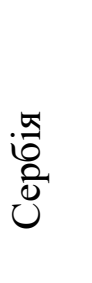 & 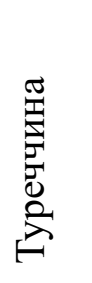 & 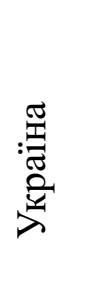 & 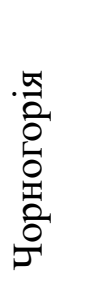 \\
\hline $\begin{array}{ll}\text { Узагальнюючий } & \text { коефіцієнт } \\
\text { освітнього } & \text { потенціалу } \\
\text { національної економіки } \\
\end{array}$ & 0,27 & 0,38 & 0,42 & 0,37 & 0,91 & 0,54 & 0,15 & 0,88 & 0,68 \\
\hline $\begin{array}{ll}\text { Узагальнюючий } & \text { коефіцієнт } \\
\text { наукового } & \text { потенціалу } \\
\text { національної економіки } \\
\end{array}$ & 0,02 & 0,23 & 0,19 & 0,21 & 0,2 & 0,73 & 0,76 & 1,13 & 0,21 \\
\hline $\begin{array}{ll}\text { Узагальнюючий } & \text { коефіцієнт } \\
\text { iнформаційного } & \text { потенціалу } \\
\text { національної економіки }\end{array}$ & 1,08 & 0,05 & 0,4 & 0,35 & 0,36 & 0,41 & 0,6 & 0,5 & 0,74 \\
\hline $\begin{array}{ll}\text { Узагальнюючий } & \text { коефіцієнт } \\
\text { людського } & \text { потенціалу } \\
\text { національної економіки }\end{array}$ & 0,12 & 0,6 & 0,5 & 0,56 & 0,62 & 0,55 & 0,05 & 0,95 & 0,87 \\
\hline $\begin{array}{ll}\text { Iнтегральний } & \text { коефіцієнт } \\
\text { iнноваційного } & \text { потенціалу } \\
\text { національної економіки }\end{array}$ & 0,03 & 0,16 & 0,13 & 0,12 & 0,2 & 0,3 & 0,06 & 0,69 & 0,3 \\
\hline
\end{tabular}

Далі, зважаючи на мету і завдання даного дослідження, було проаналізовано динаміку інтегрального коефіцієнта та складових інноваційного потенціалу України впродовж 2014-2018 рр. (рис. 2).

Щодо динаміки узагальнюючих коефіцієнтів складових інноваційного потенціалу національної економіки

України, то найбільш високим в аналізований період залишався узагальнюючий коефіцієнт наукового потенціалу, який збільшився 3 1,09 у 2014 р. до 1,18 у 2018 р. Слід вказати на важливу роль у цьому процесі 
великої кількості науково-технічних також розгалужену систему об'єктів кадрів і їх видавничу активність, а освітньої і наукової інфраструктури.

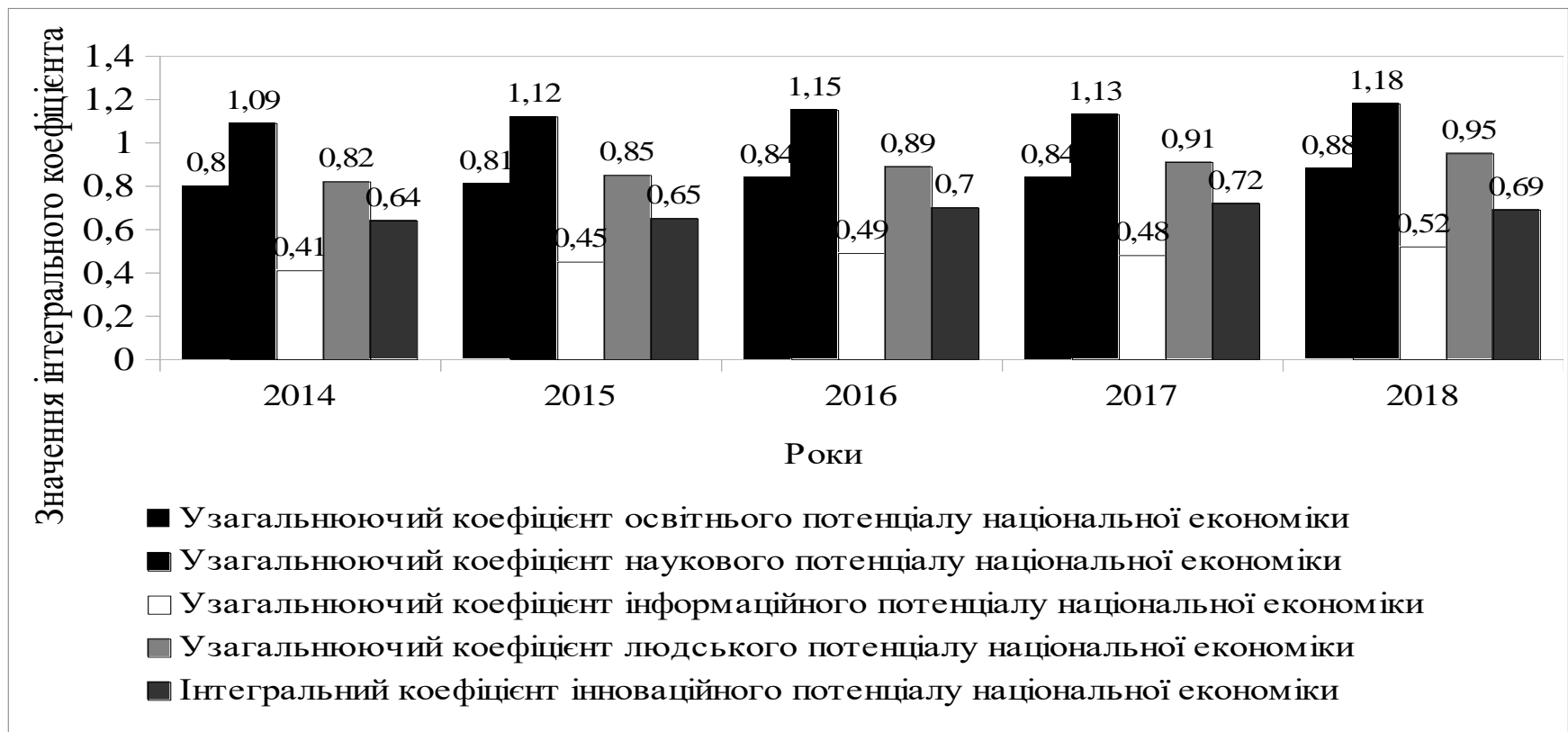

Рис. 2. Динаміка інтегрального коефіцієнта та складових інноваційного потенціалу національної економіки України на етапі європейської інтеграції та євроатлантичного співробітництва

Подібною є і динаміка узагальнюючого коефіцієнта освітнього потенціалу національної економіки України, яка впродовж 2014-2018 рр. також мала помірну тенденцію до зростання, що свідчить про високий рівень конкурентоспроможності висококваліфікованих працівників та їх потенційні можливості як на внутрішньому, так i зовнішньому ринку праці. Натомість значення узагальнюючого коефіцієнта інформаційного потенціалу було невисоким, що дає підстави стверджувати про те, що в Україні глобальні цифрові технології, інтернет-платформи, електронні гроші, електронні засоби зв'язку, мас-медіа, блоги, мікроблоги та системи штучного інтелекту і досі залишаються недостатньо поширеними. В цілому, динаміка інтегрального коефіцієнта інноваційного потенціалу національної економіки України впро- довж 2014-2018 pр. не була сталою i варійювалася у межах від 0,65 до 0,72, що підтверджує думку багатьох вітчизняних експертів [5-7] і науковців [1; $4 ; 8]$ про технологічну відсталість господарського комплексу України та неефективність функціонування іï інноваційної системи.

Отже, незважаючи на високий рівень інноваційного потенціалу національної економіки України, складним i суперечливим залишається питання ефективності його використання, що проявляється у невисокій ринковій вартості інтелектуальних активів країни і обумовлено недостатньою державною підтримкою галузей 3 високою доданою вартістю, нерозвиненістю державно-приватного партнерства у сфері реалізації інноваційних проектів, відсутністю належних інституційних умов для організації та ведення 
наукоємного бізнесу, недосконалістю нормативно-правової бази у сфері захисту об'єктів інтелектуальної власності (патентів, ліцензій, авторських свідоцтв, промислових знаків, "ноухау” та ін.), а також низьким рівнем оплати праці науково-педагогічних працівників. В результаті науковотехнічні розробки у вигляді нових програмних та/або промислових продуктів, створені українськими дослідниками i винахідниками, комерційно реалізуються в інших, більш розвинених країнах світу (Німеччині, США, Китаї, Нідерландах, Швейцарії, Південній Кореї, Гонконзі), створюючи та підвищуючи наукоємність ВВП цих країн. Вирішення означених проблем актуалізує перед сучасною наукою i практикою розробку імплементаційного механізму підвищення ефективності використання інноваційного потенціалу національної економіки України на етапі європейської інтеграції та євроатлантичного співробітництва. Тому на третьому етапі дослідження було запропоновано наступне.

По-перше, необхідною вважаємо докорінну зміну пріоритетів у розподілі бюджетних коштів у бік фінансування нових, більш прогресивних технологій. Відомо, що найбільш успішні країни-члени СС (Австрія, Велика Британія, Італія, Люксембург, Нідерланди, Німеччина) щороку виділяють понад $2 \%$ коштів державного бюджету на проведення, комерціалізацію та реалізацію нових наукових розробок $\mathrm{i}$ досліджень, що забезпечує їм економічне та політичне лідерство навіть в умовах гострої конкурентної взаємодії [7, с. 194-199]. У той же час в Україні питома вага витрат на науку та інно- ваційну діяльність впродовж 20142018 рр. варіювалася у межах від 0,5 до $0,9 \%$ ВВП, що не відповідає ані загальноєвропейським стандартам, ані ключовим завданням “Доктрини збалансованого розвитку "Україна-2030” [3] i тим самим зменшує іiі шанси зайняти конкурентні позиції у сучасній “світ-системі”. Окрім того, особливої актуальності набуває оновлення матеріально-технічної бази наукових і науково-виробничих центрів, оскільки це сприятиме реорганізації та вдосконаленню процесів виробництва, скороченню життєвих циклів продукції, а відтак і прискоренню технологічної модернізації промислового комплексу України.

По-друге, необхідно створити більш сприятливі інституційні умови для ведення наукоємного бізнесу. 3 одного боку, слід суб'єктам малого іннноваційного підприємництва або надати пільгові умови оподаткування, або взагалі звільнити їх від сплати податків і зборів на період від 1 до 3 років. 3 іншого боку, слід суттєво спростити доступ українських новаторів до фінансових ресурсів. На нашу думку, найбільш дієвими є такі технології фінансування стартап проектів: краудфандинг - технологія колективного фінансування, заснована на добровільних засадах і внесках фізичних осіб (проекти "Kickstarterr", Artist Share, Crowd Valley, Indie Gogo, Joby, Kickstarter, Rocket Hub, Sponsume, Seedmatch, Companisto, Peerbackers, Startup Addict, New Jelly, Microryza, Quirky, iAMscientist, Start Some Good та ін.); краудінвестмент - технологія колективного фінансування, заснована на принципах пайової участі, коли ін- 
вестор може отримати частину акцій компанії в обмін на свій внесок (платформа Fundable.com); краудлендінг технологія кредитування одних фізичних осіб іншими фізичними або юридичними особами (платформи Lendingclub.com, Zopa.com, Renrendai.com, Trustbuddy.com, Auxmoney.com та ін.); залучення так званих "бізнес-янголів" - приватних інвесторів, які вкладають кошти у високоризиковані інноваційні та смартпроекти (DN Capital, DST Capital, Goldman Sachs, J. C. Flowers \& Co., Kleiner Perkins, TCV, Victorypark Capital та ін.).

По-третє, потребує суттєвого удосконалення організаційно-економі чний механізм захисту прав інтелектуальної власності. Мова йде про те, що на даний час в Україні майже відсутній прямий зв'язок між фундаментальною наукою і промисловим виробництвом, що призводить до розбалансованості ринку праці та неефективної роботи науково-дослідних інституцій. Ми пропонуємо взяти "на озброєння" успішний європейський досвід створення в університетах i наукових установах відділів трансферу технологій, коворкінгів, офісів комерціалізації наукових розробок, які дають змогу європейським вченим i дослідникам отримувати об'єктивні дані щодо рівня прибутковості розроблених проектів, процедури їх патентування, ліцензування і навіть продажу.

Висновки. Проведене дослідження показало, що серед дев'яти країн, які мають на меті приєднатися до $\mathrm{CC} \mathrm{i}$ НАТО і тому на даний час знаходяться на етапі складних структурноринкових реформ, Україна за рівнем інноваційного потенціалу посідає перше місце і має найбільші потенційні можливості для успішної конвергенції з єдиною господарською системою ЄС і залучення глобальних інвестиційних ресурсів. У той же час складним і суперечливим залишається питання ефективності його використання, що проявляється у невисокій ринковій вартості інтелектуальних активів країни i обумовлено недостатньою державною підтримкою галузей 3 високою доданою вартістю, нерозвиненістю державно-приватного партнерства у сфері реалізації інноваційних проектів, відсутністю належних інституційних умов для організації та ведення наукоємного бізнесу, недосконалістю нормативно-правової бази у сфері захисту об'єктів інтелектуальної власності (патентів, ліцензій, промислових знаків, “ноу-хау” та ін.), а також низьким рівнем оплати праці науковопедагогічних працівників. Для вирішення цих проблем пропонується наступне: докорінна зміна пріоритетів у розподілі бюджетних коштів у бік фінансування нових, більш прогресивних технологій; створення більш сприятливих інституційних умов для ведення наукоємного бізнесу; суттєве удосконалення організаційно-економічного механізму комерціалізації науково-дослідних робіт і захисту прав інтелектуальної власності. Виважене використання означених заходів сприятиме фундаментальній трансформації ринку інтелектуальної власності, створенню прозорих схем ліцензування нових відкриттів, а також отриманню максимального ефекту мультиплікації від європейської інтеграції та євроантлантичного співробітництва. 
Список використаної літератури

1. Андрощук Г. О., Давимука С. А., Федулова Л. І. Національні інноваційні системи: еволюція, детермінанти результативності. Київ: Парламентське видавництво, 2015. $512 \mathrm{c}$.

2. Гусейнова А., Шукурова А., Гусейнли А. Основы и анализ инновационного потенциала. Наука, технології, інновації. 2017. № 2.

3. Жилінська О. Україна 2030: Доктрина збалансованого розвитку. Львів : Кальварія, 2017. 164 с.

4. Ляшенко В. І., Вишневський В. І. Цифрова модернізація економіки України як можливість проривного розвитку. Київ, 2018. 252 с. URL: http://iep.com.ua/7/Lyashenko_Vishnevsky_2018.pdf

5. Пирожков С. І., Майборода О. М., Шайгородський Ю. Ж. Цивілізаційний вибір України: парадигма осмислення і стратегія дії. Київ: НАН України, 2016. $284 \mathrm{c}$.

6. Писаренко Т. В., Кваша Т. К. Стан інноваційної діяльності та діяльності у сфері трансферу технологій в Україні у 2017 році. К.: УкрIHTEI, 2018. 98 с.

7. Сіденко С. Переформатування європейської інтеграції: можливості і ризики для асоціації Україна - СС. К.: Заповіт, 2018. 214 с.

8. Сіренко К. Ю. Євроінтеграційна політика України: позитивні та негативні аспекти. Науковий вісник Ужгородського національного університету. Серія: Міжнародні економічні відносини та світове господарство. 2018. Випуск 22. Частина 3. С. 65-68.

9. Устинова К. А., Губанова Е. С., Леонидова Г. В. Человеческий капитал в инновационной экономике. Вологда: Институт социально-экономического развития территорий РАН, 2015. 195 с.

10. Шваб К. Четвёртая промышленная революция. М. : Эксмо, 2016. 230 с.

11. Bozkurt B. Investigating Turkey's national innovation and learning system. Oxford Review of Economic Policy. 2018. Issue 41(2).

12. Edler J., Fagerberg J. Innovation policy: what, why, and how. Oxford Review of Economic Policy. 2017. Volume 33. № 1. PP. 2-23.

13. Fagerberg J. Innovation policy: Rationales, lessons and challenges. Journal of Economic Surveys. 2017. Volume 31. № 2. PP. 497-512. 
14. Kuzkin Y., Cherkashyna T., Nebaba N., Kuchmacz B. Economic growth of the country and national intellectual capital (evidence from the post-socialist countries of the central and eastern Europe). Problems and Perspectives in Management. 2019. Volume 17. Issue 1. P. 348-359.

15. Mazzucato M., Penna C. R. Mission-oriented finance for innovation: New ideas for investment-led growth. London: Rowman \& Littlefield, 2015. 408 p.

16. Schot J., Edward W. Three frames for innovation policy: R\&D, systems of innovation and transformative change. London: University of Sussex, 2017. 27 p.

17. Vasylchenko M., Khrystenko O. National innovation system development: Evidence from the countries of the Central and Eastern Europe region. DOI: http://dx.doi.org/10.30525/978-9934-571-28-2_6

18. Weber K. M., Truffer B. Moving innovation systems research to the next level: Towards an integrative agenda. Oxford Review of Economic Policy. 2017. Issue 33(1). PP. 101-121.

19. Official site of World Intellectual Property Organization URL: www.globalinnovationindex.org.

20. Official site of State Statistics Committee of Ukraine. URL: www.ukrstat.gov.ua. 21. Official site of United Nations Organization. URL: www.un.org. 